\title{
A systematic review assessing the extent of social marketing principle use in interventions targeting children (2000-2014) ${ }^{1}$
}

\section{Introduction}

The World Health Organization indicates that childhood obesity remains among the biggest global challenges to public health in the twenty-first century (WHO, 2014). There is a growing evidence that obesity in children has been increasing around the world in the last few decades (Ayadi, 2008; Booth et al., 2003; Magarey et al., 2001; Wang and Lobstein, 2006), with one in four Australian children and one third of American children and adolescents classed as obese (Ogden et al., 2012). Further, in the European Union over $20 \%$ of school-age children are overweight or obese, and the International Obesity Taskforce estimates that worldwide there are up to 200 million school age children who are either overweight or obese, with about 22 million children under 5 year olds being classed as overweight (Deckelbaum and Williams, 2001).

Childhood obesity causes many health issues such as hyperinsulinaemia, poor glucose tolerance and a raised risk of type 2 diabetes, hypertension, sleep apnoea, social exclusion and depression (Braveman and Barclay, 2009) Obesity among children remains a serious problem later in life as obese children are at high risk of becoming overweight or obese adults, and will be at risk of increased morbidity even if they lose weight (Deckelbaum and Williams, 2001). If the current increased prevalence of childhood obesity remains unchanged, obesity will start to affect people in their adulthood, and increased levels of heart diseases, diabetes, cancer, gall bladder disease, osteoarthritis, endocrine disorders and other obesity-related health problems will impact the health of our society to even greater extent than they already do. This will be a significant cost to the governments (Lobstein et al., 2004), as up to 7\% of the total health care costs are attributable to obesity (WHO, 2003). While some of the science fuelling the obesity discourse is being questioned (Gard and Wright, 2005), a World Health Organization report points towards changing world food economy and shifting dietary patterns, such as an increase in the consumption of energy-dense foods that are high in saturated fat and low in unrefined carbohydrates, as some of the reasons behind increasing obesity rates (WHO, 2000). Our changing diet patterns combined with sedentary lifestyles, reliance on motorised transportation and the decline in physically demanding labour jobs also play an important role in the growing prevalence of overweight and obesity.

Social marketing is one of the tools used around the world to combat some of the problems associated with and leading to obesity. For example, a recent study by Carins and Rundle-Thiele (2014) identified thirty-four social marketing interventions aiming to improve healthy eating behaviours. The American Academy of Pediatrics argues that the causes of the obesity epidemic need to be tackled early in child's life (Daniels and Greer, 2008; Shonkoff, Boyce and McEwan, 2009). Calls have been made for social marketing to be included in children's preventative health strategy and practice (Barlovic, 2006), yet no previous systematic review of evidence in the area of social marketing targeting children has been identified. This paper attempts to

\footnotetext{
${ }^{1}$ The evidence synthesis on which this article was based was funded by Victorian Health Promotion Foundation (VicHealth). The funders played no role in study design, collection, analysis, interpretation of data, or in the decision to submit the paper for publication. They accept no responsibility for contents.
} 
close this gap by examining the extent that social marketing principles or benchmark criteria are (or are not) used in social marketing interventions targeting children published in peer-reviewed journals.

\section{Social Marketing}

Social marketing has been used for over 40 years to facilitate a wide range of behaviours, including responsible alcohol consumption, reduction in the prevalence of smoking and illicit drugs, improved diet and increased physical activity (Gordon et al., 2006). Social marketing is a framework relying on its commercial marketing roots to address social issues. In July 2013 the International Social Marketing Association (ISMA), European Social Marketing Association (ESMA) and the Australian Association of Social Marketing (AASM) adopted a consensus definition of social marketing stating that "social marketing seeks to develop and integrate marketing concepts with other approaches to influence behaviours that benefit individuals and communities for the greater social good" (2013).

In 2002, Alan Andreasen identified the six benchmark criteria differentiating social marketing from other behaviour change approaches. Following the publication of Andreasen's (2002) social marketing benchmark criteria alternative frameworks (see for example, French and Blair-Stevens, 2005 and Robinson-Maynard et al., 2013) have been put forward. Not all frameworks offer mutually exclusive criteria for categorisation purposes. Andreasen's (2002) framework offers mutually exclusive categories and has been used to categorise the extent social marketing has been implemented within interventions in similar social marketing reviews (Carins and Rundle-Thiele, 2014; Gordon et al., 2006). Andresen's criteria include six benchmarks. First, social marketing interventions should aim to change behaviours. While increasing awareness, changing attitudes or behavioural intentions are all important, changing behaviour must remain the penultimate aim (Donovan and Henley, 2010). Second, social marketers should use formative research to provide insights into consumers' needs, wants, behaviours and preferences, in order to inform the development of the social marketing intervention (French and Blair-Stevens, 2006). Third, segmentation should be used to differentiate between different groups within the target market, provide them with tailored marketing mixes and maximise the effectiveness of marketing activities. Fourth, marketing mix, which may include product, place, price and promotion should be used to deliver an offering that target audiences will find attractive (Elliot et al., 2014). Fifth, exchange should be considered in an attempt to lower the barriers to performing the desired behaviour and offering benefits that the target audience will consider beneficial. Finally, competition should be analysed focusing on both direct alternative behaviours and competing campaigns and marketing activities.

Considerable confusion remains about what is (and what is not) social marketing. In 2002 Alan Andreasen (2002) recommended that social marketing should comprise any one of six benchmark criteria. More recent studies (see Carins and Rundle-Thiele, 2014), that have empirically examined social marketing intervention effectiveness in the context of healthy eating in adult populations, indicate that social marketing is more likely to be effective when more of the benchmark criteria are used. For this reason, it is important to examine the extent that Andreasen's (2002) benchmark criteria are used by social marketers who are seeking to change behaviours in young consumers, to understand how further improvements to social marketing 
implementation can occur. Efforts to establish the extent that social marketing principles are (or are not) used assist to overcome current confusion surrounding social marketing. A systematic literature review of social marketing interventions targeting children was first undertaken and an assessment of the extent of social marketing benchmark criteria use in interventions followed.

\section{Methods}

Following the systematic literature review procedures outlined in Carins and RundleThiele (2014) a search was conducted to identify social marketing interventions targeting children aged 12 and under, and published between January 2000 and June 2014. Nine databases (Table 1) were searched using the following terms: children* or kids* AND intervention* or Randomi\#ed Controlled Trial or evaluation or trial or campaign* or program* or study or studies AND social marketing. The variance of records between databases can be attributed to the size and the specialisations of each database and how closely they relate to the search terms. ProQuest, for example, is made up of twenty databases.

Table 1: Databases and articles retrieved in initial search

\begin{tabular}{|l|c|}
\hline \multicolumn{1}{|c|}{ Database } & $\begin{array}{c}\text { Number of articles } \\
\text { retrieved }\end{array}$ \\
\hline EBSCO All Databases & 96 \\
\hline Emerald & 0 \\
\hline INSPEC (Web of Knowledge) & 0 \\
\hline Medline (R; and InProcess) (Ovid) & 132 \\
\hline ProQuest All Databases & 172 \\
\hline PsycINFO (Ovid) & 68 \\
\hline ScienceDirect & 1 \\
\hline Taylor \& Francis & 0 \\
\hline Web of Science & 182 \\
\hline Total & $\mathbf{6 5 1}$ \\
\hline
\end{tabular}

All downloaded records were collated using Endnote. As multiple databases include the same journals, duplicate records had to be removed reducing the number of unique articles to 320. In the next stage unqualified records including newspaper articles, conference papers and records published before January 2000 and not in English were removed. Then, titles and abstracts of the remaining papers were reviewed and records classified into the following exclusion criteria were excluded: formative research, papers with no social marketing claim, review/conceptual papers, and interventions not targeting children under the age of 12 . 
Following the application of the exclusion criteria thirty-five articles including evaluations of social marketing interventions targeting children aged 12 years and under were identified. Backward and forward searching using authors' names and websites, intervention names, Google Scholar, 'Publish or Perish' and reference lists was completed to identify a further fourty-six relevant social marketing interventions and other articles providing additional information about the identified interventions. In total, eighty-one articles were included in the analysis covering twenty-three social marketing interventions. Figure 1 shows the literature search process, and the full list of eighty-one papers for each social marketing intervention can be found in Appendix 1. All interventions included in this paper self-identified as social marketing interventions. Interestingly, all interventions included in this paper are in the field of obesity. The majority of interventions identified in this review targeted healthy eating and/or physical activity and to a lesser extent interventions targeted areas such as diabetes, which is associated with obesity. 
Figure 1: Flowchart of the literature search process

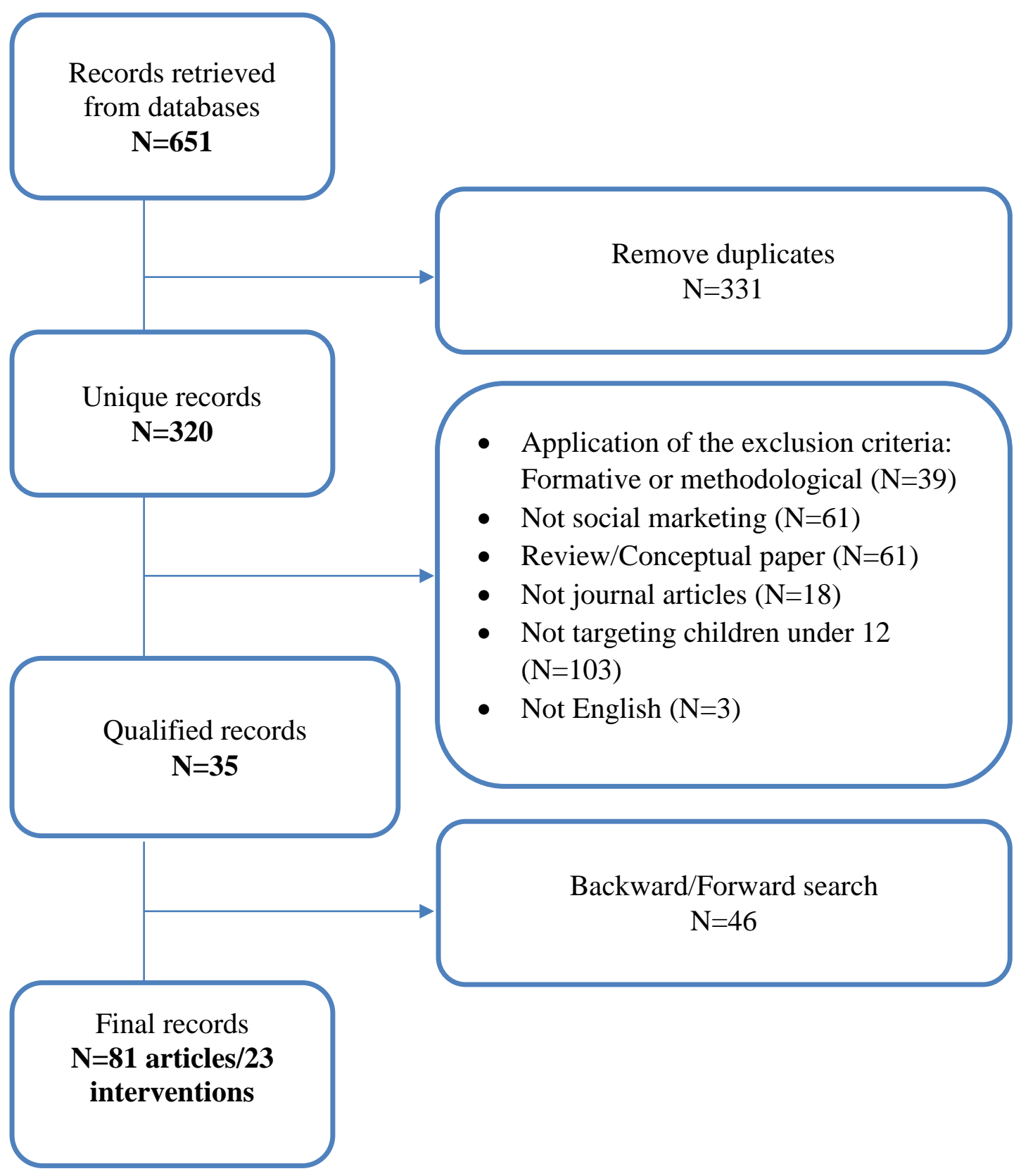

All identified articles were analysed to identify any potential evidence of each of Andreasen's (2002) six social marketing benchmark criteria: the aim to change behaviours (and factors known to influence behavior change in the longer term), distinct formative research to inform the intervention, market segmentation to increase the effectiveness of the intervention, clearly identified exchange, the use of marketing mix, and consideration of competition reported. Further analysis was also completed to determine the target audience for each intervention and identify all intervention outcomes and results reported in the articles. In order to increase interrater reliability all identified relevant excerpts were reviewed, compared and discussed by four social marketing researchers. If no evidence of any of the assessment was identified by any of the researchers a 'not reported' outcome was assigned to the intervention against the specific benchmark criterion. 


\section{Results and Discussion \\ Target audiences}

Each intervention was analysed to determine its exact target audiences. Seventeen of the twenty-three interventions had targeted multiple groups, indicating the awareness that children are not always in control of their behaviour and other stakeholders (e.g. parents, teachers and community members) can have a significant impact on a child's physical activity levels and food consumption (Ayadi, 2008). Among those interventions five also included parents and school staff (Cork, 2008; Foster et al., 2008; Levin et al., 2002; Sallis et al., 2003; Sanigorski et al., 2008). While fifteen interventions targeted both the parents and the children, parents were mostly considered as a secondary target audience except in two campaigns (Croker et al., 2012; Richards et al., 2009). Community was a secondary target audience in four interventions (Bachar et al., 2006; Henley et al., 2011; Sanigorski et al., 2008; Sayers et al., 2009).

\section{Outcomes of the interventions}

Although all of the social marketing interventions described in this paper targeted children under the age of 12, they were carried out in a diverse range of contexts and often included different outcome measures. We were hence unable to follow standard meta-analytical procedure and focused on identifying whether positive, negative or no effect was observed, without attempting to determine the size of the effect. Five main types of outcomes were included in the analysis: behavioural, behavioural intentions, attitudinal, awareness, and policy outcomes.

The main goal of social marketing intervention is behaviour change (Coffman, 2002). Sixteen out of the twenty-three interventions reported positive behavioural effects, representing over two-thirds of the identified studies, while seven interventions reported no behavioural change. None of the reviewed interventions reported any negative behavioural outcomes.

\section{Andreasen's (2002) benchmark criteria}

Table 2 presents the assessment of each of the twenty-three social marketing interventions against Andreasen's (2002) six social marketing benchmark criteria. None of the interventions gave evidence that they addressed all of the benchmark criteria, and only two interventions addressed five of the six social marketing benchmark criteria (Bellows et al., 2013; Sanigorski et al., 2008). In both interventions the only benchmark criterion that was lacking was audience segmentation. Fifteen interventions reported the use of three or less benchmark criteria. 
Table 2: Assessment of the use of Andreasen’s benchmark criteria in social marketing interventions

\begin{tabular}{|c|c|c|c|c|c|c|c|c|c|}
\hline Author(s) & Behaviour & Target Audience & $\begin{array}{c}\text { No. of } \\
\text { SMBC } \\
2\end{array}$ & 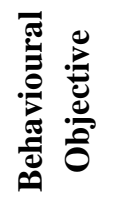 & 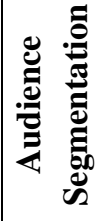 & 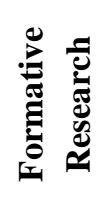 & 范 & 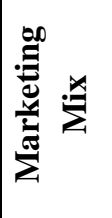 & 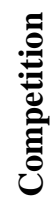 \\
\hline Bellows et al., 2013 & Physical activity & 3-5 years & 5 & $\checkmark(+)^{3}$ & $x$ & $\checkmark$ & $\checkmark$ & $\checkmark(4)^{4}$ & $\checkmark$ \\
\hline Sanigorski et al., 2008 & Healthy eating and physical activity & 4-12 years & 5 & $\checkmark(+)$ & $x$ & $\checkmark$ & $\checkmark$ & $\checkmark(4)$ & $\checkmark$ \\
\hline Bachar et al., 2006 & Reduce diabetes & $9-10$ years & 4 & $\checkmark(+)$ & $x$ & $\checkmark$ & $x$ & $\checkmark(3)$ & $\checkmark$ \\
\hline Cork, 2008 & Healthy eating and physical activity & 4-11 years & 4 & $\checkmark(+)$ & $x$ & $\checkmark$ & $x$ & $\checkmark(2)$ & $\checkmark$ \\
\hline DeBar et al., 2009 & Physical activity and healthy eating & 11-14 years & 4 & $\checkmark(+)$ & $x$ & $\checkmark$ & $x$ & $\checkmark(4)$ & $\checkmark$ \\
\hline Keihner et al., 2011 & $\begin{array}{l}\text { Healthy eating (and later increased physical } \\
\text { activity) }\end{array}$ & 9-11 years & 4 & $\checkmark(+)$ & $\checkmark$ & $\checkmark$ & $x$ & $\checkmark(3)$ & $x$ \\
\hline Kremer et al., 2011 & Physical activity and healthy eating & 12-18 years & 4 & $\checkmark(*)$ & $x$ & $\checkmark$ & $x$ & $\checkmark(2)$ & $\checkmark$ \\
\hline Levine et al., 2002 & Healthy eating & $\begin{array}{l}\text { Kindergarten to } 4 \\
\text { years }\end{array}$ & 4 & $\checkmark(+)$ & $\checkmark$ & $x$ & $x$ & $\sqrt{ }(2)$ & $\checkmark$ \\
\hline Croker et al., 2012 & Healthy eating and physical activity & 5-11 years & 3 & $\checkmark(*)$ & $x$ & $\checkmark$ & $x$ & $x$ & $\checkmark$ \\
\hline Henley et al., 2011 & Childhood obesity & 3-12 years & 3 & $\checkmark(+)$ & $x$ & $\checkmark$ & $x$ & $\checkmark(3)$ & $x$ \\
\hline
\end{tabular}

2 Social Marketing Benchmark Criteria (Andreasen, 2002)

3 + positive behavioural outcomes reported, * no behavioural change reported

${ }^{4}$ The number of Ps reported in the intervention 


\begin{tabular}{|c|c|c|c|c|c|c|c|c|c|}
\hline Author(s) & Behaviour & Target Audience & $\begin{array}{c}\text { No. of } \\
\text { SMBC } \\
2\end{array}$ & 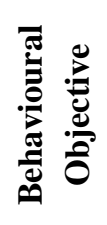 & 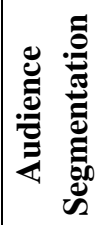 & 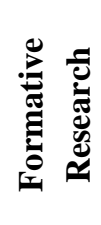 & 茴 & 离 & 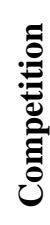 \\
\hline Hoffman et al., 2009 & Healthy drinking & $11-13$ years & 3 & $\checkmark(*)$ & $x$ & $\checkmark$ & $x$ & $\checkmark(4)$ & $x$ \\
\hline Huhman et al., 2008 & Physical activity & 9-13 years & 3 & $\checkmark(+)$ & $x$ & $\checkmark$ & $x$ & $\checkmark(3)$ & $x$ \\
\hline Richards et al., 2009 & Healthy eating & 2-4 years & 3 & $\checkmark(+)$ & $x$ & $\checkmark$ & $x$ & $\checkmark(2)$ & $x$ \\
\hline Thackery et al., 2002 & $\begin{array}{l}\text { Fruit and vegetable consumption among middle } \\
\text { school students }\end{array}$ & 7th-8th grade & 3 & $\checkmark(+)$ & $x$ & $\checkmark$ & $x$ & $\checkmark(3)$ & $x$ \\
\hline Evans et al., 2006 & $\begin{array}{l}\text { Increase fruit and vegetable intake, change the } \\
\text { home environment }\end{array}$ & $9-10$ years & 2 & $\checkmark(*)$ & $x$ & $x$ & $x$ & $\checkmark(2)$ & $x$ \\
\hline Foster et al., 2008 & Overweight prevention & 9-11 years & 2 & $x(+)$ & $x$ & $\checkmark$ & $x$ & $x$ & $\checkmark$ \\
\hline Johnson et al., 2007 & Healthy eating & 3-5 years & 2 & $x$ & $x$ & $\checkmark$ & $x$ & $\checkmark(3)$ & $x$ \\
\hline Johnston et al., 2009 & Healthy dietary choices & $6-11$ years & 2 & $\checkmark(+)$ & $x$ & $x$ & $x$ & $\checkmark(2)$ & $x$ \\
\hline Pempek \& Calvert, 2009 & Consumption of healthy and less healthy snacks & $9-10$ years & 2 & $\checkmark(+)$ & $x$ & $x$ & $x$ & $\checkmark(2)$ & $x$ \\
\hline Raju et al., 2010 & Healthy food choices & $6-13$ years & 2 & $\checkmark(+)$ & $x$ & $x$ & $x$ & $\checkmark(2)$ & $x$ \\
\hline Sallis et al., 2003 & Physical activity and reducing fatty food intake & 11- 14 years & 2 & $\checkmark(+)$ & $x$ & $x$ & $x$ & $\checkmark(3)$ & $x$ \\
\hline Sayers et al., 2009 & Physical activity & Elementary school & 2 & $\checkmark(+)$ & $x$ & $x$ & $x$ & $\checkmark(4)$ & $x$ \\
\hline Atlantis et al., 2008 & Physical activity & $10-12$ years & 1 & $x$ & $x$ & $\checkmark$ & $x$ & $x$ & $x$ \\
\hline
\end{tabular}




\section{Behavioural objective}

Behaviour change can be found in all social marketing benchmark criteria frameworks (Andreasen, 2002; French and Blair-Stevens, 2006) and it is fundamental to evaluating intervention success. French and Blair-Stevens (2006) stated that social marketing must have "a clear focus on behaviour, based on a strong behavioural analysis, with specific behaviour goals" (p.1). All of the studies analysed in this paper stated a specific aim for their intervention, and twenty out of the twenty-three interventions targeting children under 12 aimed to change behaviours, and sixteen of them delivered positive behavioural outcomes. One out of the three interventions which did not have any behavioural objectives delivered positive behavioural outcomes (Foster et al., 2008). Fifteen interventions aimed to change more than one behaviour for example, Sanigorski et al.'s (2008) intervention had eight specific behaviour change aims: reducing television viewing, reducing sugar drinks and increasing water consumption, reducing energy dense snacks and increasing fruit intake, increasing active play after school and weekends, and increasing active transport to school.

Two interventions sought to influence behavioural intentions towards performing a specific behavior: increasing children's willingness to try new foods (Jonson et al., 2007) and increasing the likelihood that children would internalise healthier behaviours (DeBar et al., 2009). Six interventions also aimed to change attitudes. For example, Cork (2008) aimed to change children's habits and attitudes towards healthy living and provide them with the tools and knowledge to encourage lifelong participation in physical activities and consumption of healthy food and drink. Awareness was an aim for nine interventions, and ten interventions made an attempt to change policy.

\section{Segmentation}

Segmentation relies on dividing a total population targeted by an intervention into smaller groups and delivering marketing activities and materials tailored to each of the groups and reflecting their needs. Andreasen's (2002) stated that careful segmentation of target audiences is necessary in order to "ensure maximum efficiency and effectiveness in the use of scarce resources" (p.104). Segmentation can be based on one or more of demographic, psychographic, geographic, behavioural and epidemiological factors. Segmentation is based on the principle understanding that populations are typically heterogeneous (Evers et al., 2013) and that groups with similar needs and wants can be identified. An intervention was classified as using segmentation if an evidence of adapting at least one of the marketing mix components to different groups within the target population was identified. Only two social marketing interventions reported using segmentation and both of them delivered positive behavioural outcomes (Keihner et al., 2011; Levine et al., 2002). Keihner et al. (2011) used ten grade-specific activities for Grade 4 and Grade 5 to provide stronger links to the core academic subjects of the California Content Standards. In a similar way, Levine et al. (2002) also used grade-specific activities for three different groups of children: pre-kindergarten and kindergarten, first and second grades, and third through fifth grades.

\section{Formative research}

Formative research is essential to any social marketing intervention (Andreasen, 2002) providing an opportunity for the social marketer to learn about the target 
audience and how to best design an intervention for that specific audience. Eleven interventions reported use of two or more formative research methods to inform intervention development. Use of both focus groups and interviews was the most popular combination ( $\mathrm{n}=7$ ) (Bachar et al., 2006; Bellows et al., 2013; Croker et al., 2012; DeBar et al., 2009; Hoffman et al., 2009; Huhman et al., 2008; Thackery et al., 2002). Over half of the interventions analysed $(n=12)$ used one or more formative research method. Focus groups $(n=9)$, interviews $(n=8)$ and surveys $(n=8)$ were the most popular methods of formative research. Including additional stakeholders outside of the target audience in formative research is a good way to learn unique insights and gauge the endorsement of secondary groups. For example, Bellows et al. (2013) used key informant interviews and focus groups with Head Start and preschool teachers and parents respectively, to examine current physical activity practices, as well as attitudes, opinions, and desired wants and needs for physical activity materials. Last but not least, seven of the interventions in this review did not incorporate formative research into their study design.

\section{Exchange}

According to French and Blair-Stevens (2006), in the context of social marketing exchange describes something that a person has to give up in order to get the proposed benefit of the intervention. In this review exchange was treated as "direct exchange”, meaning that if something tangible (e.g. money) or intangible (e.g. time) that needs to be given up simultaneously to get a direct benefit was identified in an intervention, the intervention was classified as using the social marketing exchange. Over time, performing an exchange or multiple exchanges is expected to lead to the desired behaviour. Understanding what the alternatives are to the desired behaviour can provide insight into what would represent a valuable exchange to the target audience. Similar to commercial marketing, social marketers must know the behaviours that are competing with the behavioural aim of an intervention. Two interventions identified in this review included clear evidence of exchange. Sanigorski et al. (2008) demonstrated some evidence of exchange for children with the creation of lunch packs sold during the intervention. The healthy lunch packs were provided to students in exchange for money.

\section{Marketing mix}

Consistent with previous literature reviews (Carins and Rundle-Thiele, 2014), if evidence of at least two of the marketing mix elements (product, place, price or promotion) was reported in an intervention, the intervention was classified as using a marketing mix. Social marketing campaigns involve the use of multiple strategies, including the 4Ps of the traditional marketing mix: product, price, place, and promotion (Evers, 2013). In this review, five interventions employed the entire marketing mix and seven interventions used three elements of the marketing mix (see Table 2). All of the interventions except Pempek and Calvert (2009) used the promotional aspect of the marketing mix, and three interventions relied solely on promotions to achieve their aims (Atlantis et al., 2008; Croker et al., 2012; Foster et al., 2008).

Product is the benefits derived from an exchange by the target audience and any goods and services required to support the desired behaviour (Lee and Kotler, 2011). An overwhelming majority of the interventions in this review reported using products $(\mathrm{n}=19)$. Tangible products included for example, a recipe/cook book(s) (Cork, 2008; 
Keihner et al., 2011; Thackery et al., 2002), healthy food combo pack for school lunches available at the school cafeteria (Sanigorski et al., 2008), provision of school healthy meal programs and physical education class plans to be used by teachers (DeBar et al., 2009), music CD for children to provide a musical journey to help tie the nutrition and activity concepts together (Bellows et al., 2013), and interactive classroom lessons, including classroom materials, training resources, and technical assistance for teachers, and focusing on making food choices and then assessing those food choices (Levine et al., 2002). Further, some of the intangible products included events such as walk to school day and cooking classes (Kremer et al., 2011; Thackery et al., 2002), walking school bus (Sanigorski et al., 2008; Sayers et al., 2009), as well as training in healthy food preparation for cafeteria staff and professional development for teachers in physical education curriculum (Sanigorski et al., 2008), and an online game educating children about healthier food choices (Pempek and Calvert, 2009).

Evidence of promotion was identified in 22 interventions. The social marketing interventions in this review used a wide range of promotional tools to raise awareness, enforce a particular message or to promote social marketing activities. The most commonly used tools were promotional events $(n=11)$ such as Athletics Week, Parent's Day, Healthy Week, National Food and Water Day (Kremer et al., 2011), followed by leaflets and pamphlets $(n=5)$, posters $(n=7)$, newsletters targeted at parents and adults $(n=5)$, banners and public service announcements $(n=4)$. Television advertising was found in five interventions (Atlantis et al., 2008; Bachar et al., 2006; Huhman et al., 2008; Johnston et al., 2009; Keihner et al., 2011). Four interventions (Bellows et al., 2013; Croker et al., 2012; Johnston et al., 2009; Kremer et al., 2011) used digital promotional methods in the form of websites either created specifically for the intervention or as an addition to a current website.

Place as a location where the target audience enters into an exchange was identified in fourteen interventions, with school premises (e.g. cafeteria) and its surroundings being the most common location $(\mathrm{n}=13)$. The interventions reported in Huhman et al. (2008) used a number of places: community recreational centres, camps, schools, festivals, sporting events and shopping centres where play areas and street and interactive games were located. Adoption costs in social marketing may be monetary or non-monetary in nature, including time, effort and energy required to perform the behaviour, perceived psychological risks and losses, and physical discomforts that may be associated with the behaviour (Lee \& Kotler 2011). Price as the cost or sacrifice exchanged for the product was explicitly identified in four interventions and included time, the financial cost of healthy lunch packs or cafeteria food (Bellows et al., 2013; DeBar et al., 2009; Sanigorski et al., 2008). Sayers et al. (2009) considered price by giving away bicycles, which were donated and repaired by volunteers before being provided to low-income families, free of charge.

\section{Competition}

Andreasen's (2002) social marketing benchmark criteria require recognising and addressing the competition of the behaviour targeted by an intervention. The social marketer has to understand what other behaviours are competing for the chosen target audience's time and attention in order to develop strategies that minimize the impact of the competition (Andreasen, 2002). An intervention was classified as meeting the competition benchmark if at least one direct (e.g. other campaign aiming to change 
the same behaviour) or indirect (e.g. other behaviours competing for the target audience's time and attention) form of competition was identified in the analysed materials. Nine interventions mentioned competition to their desired behaviour(s), and seven of them reported sedentary behaviours, sugary drinks, energy dense snacks and fatty foods as competition (Bachar et al., 2006; Croker et al., 2012; DeBar et al., 2009; Foster et al., 2008; Kremer et al., 2011; Levine et al., 2002; Sanigorski et al., 2008). Further, Cork (2008) reported internal competition from other programs run by their organization and highlighted that when developing the intervention they had to first consider this internal competition before the external competition.

\section{Conclusion, Limitations and Future research}

This paper sought to review social marketing interventions targeting children under the age of 12, published in peer-reviewed journals, to identify the extent that social marketing principles have been used in social marketing. There is growing evidence that social marketing can be successfully used to improve healthy eating behaviours (Carins and Rundle-Thiele, 2014), one of the main causes of obesity. Yet, considerable confusion continues to exist with a poor understanding of what social marketing is (and is not). The current study was undertaken to update the evidence base on the extent that social marketing principles outlined by Alan Andreasen in 2002 are employed in social marketing interventions targeting children.

The results indicate that all of the interventions analysed in this review targeted behaviours associated with either physical activity or healthy eating among children under the age of 12 . Although none of the social marketing interventions employed all six of Andreasen's (2002) benchmark criteria, seventeen of the studies reported positive behavioural outcomes, and no negative outcomes were reported. This indicates that social marketing can change behaviour among children aged under 12 . Previous studies identified many examples of social advertising masquerading as social marketing (for example, see Carins and Rundle-Thiele, 2014). In this review two of the three interventions which relied solely on promotions reported no positive outcomes. This supports earlier studies (Carins and Rundle-Thiele, 2014) indicating that social advertising is less effective than social marketing interventions employing more of the social benchmark criteria (e.g. a marketing mix offering the opportunity for exchange).

With a growing concern about the prevalence of obesity among children (Ogden et al., 2012), social marketing offers an effective approach to increase physical activity and healthy eating. This review provides examples of use of each of six social marketing benchmarks to provide a clear understanding of what is (and what is not) social marketing. In 2002 Alan Andreasen indicated that social marketing occurs if any one of six social marketing benchmark criteria are used. More recent evidence (Carins and Rundle-Thiele, 2014) indicates achieving positive change is more likely when more of the social marketing benchmark criterion are used. The current review indicates that effectiveness can be achieved without full use of all six of Andreasen's (2002) benchmark criterion. Taken together, evidence indicates that social marketing is likely to deliver superior outcomes to information only campaigns and as such social marketers need to extend beyond sole use of communications to deliver behavior change. Moreover, social marketers may improve social marketing intervention effectiveness with full use of all six of Andreasen's (2002) benchmark criteria (Carins and Rundle-Thiele, 2014). 
Evidence of audience segmentation, exchange and competition analysis in the 23 interventions was scarce. Social marketers need to develop a comprehensive understanding of these principles. This paper outlines examples of reported use of each social marketing benchmark to extend our understanding. Some of the interventions targeted children between the ages of 4 and 12, yet significant differences between children in this age bracket call for a more targeted approach reflecting the developmental differences between children aged between 4 and 12 years old. Further opportunities exist in the identification of competing behaviours and offerings which contribute toward children's obesogenic behaviours. Obese children often grow up to be overweight or obese adults, and therefore remain at risk throughout their life (Deckelbaum and Williams, 2001). Future studies should look into long-term effectiveness of social marketing interventions targeting children in providing them with skills and resources facilitating healthy lifestyles in adulthood. Finally, the interventions identified in this review were all focused in the context of obesity. Additional opportunities exist to extend the implementation of social marketing into other contexts such as bullying, cyber safety, fire safety and participation in education.

This study has several important limitations which should be considered when interpreting the results. First, it includes only studies which self-identified as social marketing, and therefore education, public health and other interventions which may exhibit some of the characteristics of social marketing were excluded. Yet combating the obesity epidemic requires concerted efforts across all disciplines, supporting both children and parents in creating healthy lifestyle choices and eliminating obesogenic environments. Further work should therefore consider all types of interventions targeting children regardless of their theoretical foundations to develop a greater understanding of what works in the obesity context and why it works. Second, although the roles of parents and teachers is crucial in providing children with alternatives to unhealthy foods and activities, this review focused on the role of social marketing rather than any of the important stakeholder groups such as food industry, retailers, schools, parents and authorities (Ayadi and Young, 2006). Future research should continue analysing the interventions focusing on the role of parents, teachers and other stakeholders influencing the development of children's healthy living habits (Ayadi, 2008). Third, the results indicated that only one of the 23 interventions identified through the process of systematic literature search was partially conducted in a non-Western context (Kremer et al., 2011, carried out in Fiji, Tonga as well as New Zealand and Australia). Yet the World Health Organization indicated that 35 out of 42 million of overweight children live in developing countries (WHO, 2014). Therefore future reviews should attempt to identify social marketing and other public health approaches to tackling the obesity problem in a non-Western context, which may require extending systematic literature review procedures beyond papers in the English language. Fourth, this study used the Andreasen's (2002) six social marketing benchmark criteria, and future work should consider alternative analytical frameworks (for example, French and Blair-Stevens, 2005; Robinson-Maynard et al., 2013) to further extend our understanding of the extent that social marketing principles are being implemented. Fifth, moving forward social marketers should develop a consensus on key outcome variables for obesity interventions. In 2013 a consensus definition of social marketing was reached (AASM, iSMA, ESMA, 2013). The approach used to reach consensus should be adopted once more focusing on 
outcomes. Consistent use of the same outcome variable(s) would permit metaanalyses to be undertaken. The use of meta-analyses would permit an understanding of the factors leading to intervention effectiveness to be built to better inform future practice in social marketing. Such efforts are important to identify which benchmark criteria enhance effectiveness and in which conditions. Finally, effort has been made to identify all sources of information about each of the 23 interventions, including peer-reviewed publications, intervention reports and websites, however it is important to note that the analysis was limited by the information provided in those sources.

\section{References}

AASM, ISMA, and ESMA (2013), Consensus definition of social marketing. Available: $\quad$ http://www.isocialmarketing.org/assets/social_marketing_definition.pdf, accessed 2 July 2014.

Andreasen, A.R. (2002), "Marketing social marketing in the social change marketplace”, Journal of Public Policy \& Marketing, Vol. 21 No. 1, pp. 3-13.

Atlantis, E., Salmon, J., and Bauman, A. (2008), “Acute effects of advertisements on children's choices, preferences, and ratings of liking for physical activities and sedentary behaviours: A randomised controlled pilot study", Journal of Science and Medicine in Sport, Vol. 11 No. 6, pp. 553-557.

Ayadi, K. (2008), "The role of school in reducing the prevalence of child obesity”, Young Consumers: Insight and Ideas for Responsible Marketers, Vol. 9 Iss: 3, pp.170-178.

Ayadi, K. and Young, B. (2006), "Community partnerships: preventing childhood obesity”, Young Consumers: Insight and Ideas for Responsible Marketers, Vol. 7 Iss: 4, pp. 35-40.

Bachar, J.J., Lefler, L.J., Reed, L., McCoy, T., Bailey, R., and Bell, R. (2006), "Cherokee Choices: a diabetes prevention program for American Indians", Preventing Chronic Disease, Vol. 3 No. 3, pp.1-9.

Barlovic, I. (2006), “Obesity, advertising to kids, and social marketing”, Young Consumers: Insight and Ideas for Responsible Marketers, Vol. 7 Iss: 4, pp.2634.

Bellows, L.L., Davies, P.L., Anderson, J., and Kennedy, C. (2013), “Effectiveness of a physical activity intervention for head start preschoolers: a randomized intervention study", The American Journal of Occupational Therapy, Vol. 67 No. 1, pp. 28-36.

Booth, M.L., Chey, T., Wake M., et al. (2003), "Change in the prevalence of overweight and obesity among young Australians, 1969-1997”, The American Journal of Clinical Nutrition, Vol. 77 No. 1 , pp. 29-36.

Braveman, P., and Barclay, C. (2009), "Health disparities beginning in childhood: a life-course perspective”, Pediatrics, Vol. 124 Sup 3, pp. 163-175.

Carins, J.E. and Rundle-Thiele, S.R. (2014), "Eating for the better: a social marketing review (2000-2012)”, Public Health Nutrition, Vol. 17 No. 7, pp. 1628-39.

Cork, S. (2008), "Beating the barriers to social marketing”, Social Marketing Quarterly, Vol. 14 No. 1, pp. 37-49.

Croker, H., Lucas, R., and Wardle, J. (2012), "Cluster-randomised trial to evaluate the 'Change for Life' mass media/social marketing campaign in the UK', BMC Public Health, Vol. 12 No. 1, pp. 404. 
Daniels, S.R., and Greer, F.R. (2008), "Lipid screening and cardiovascular health in childhood”, Pediatrics”, Vol. 122 No. 1, pp. 198-208.

DeBar, L.L., Schneider, M., Ford, E.G., Hernandez, A.E., Showell, B., Drews, K. L., ... and White, M. (2009), "Social marketing-based communications to integrate and support the HEALTHY study intervention”, International Journal of Obesity, Vol.33, pp. 52-59.

Deckelbaum, R.J. and Williams, C.L. (2001), “Childhood obesity: the health issue”, Obesity Research, Vol. 9 Suppl.: 4, pp.239-243.

Donovan, R. and Henley, N. (2010), Principles and Practice of Social Marketing: An International Perspective, Cambridge University Press.

Elliot, G., Rundle-Thiele, S.R. and Waller, D. (2014), Marketing, 3rd Edition, John Wiley and Sons, Milton, Australia.

Evans, A.E., Dave, J., Tanner, A., Duhe, S., Condrasky, M., Wilson, D., ... and Evans, M. (2006), "Changing the home nutrition environment: effects of a nutrition and media literacy pilot intervention”, Family \& Community Health, Vol. 29 No. 1, pp. 43-54.

Foster, G.D., Sherman, S., Borradaile, K.E., Grundy, K.M., Vander Veur, S.S., Nachmani, J., ... and Shults, J. (2008), "A policy-based school intervention to prevent overweight and obesity”, Pediatrics, Vol. 121 No. 4, pp. 794-802.

French, J. and Blair-Stevens, C. (2005), The Big Pocket Guide to Social Marketing, (1st edition) National Social Marketing Centre, The National Consumer Council, London.

French J. and Blair-Stevens C. (2006), Social Marketing National Benchmark

Criteria. London: UK National Social Marketing Centre; available: http://www.snh.org.uk/pdfs/sgp/A328466.pdf, accessed 2 July 2014.

Gard, M. and Wright, J. (2005), The Obesity Epidemic: science, morality and ideology, London: Routledge.

Gordon, R., McDermott, L., Stead, M. andAngus, K. (2006), The effectiveness of social marketing interventions for health improvement: What's the evidence? Public Health, Vol. 120 No. 12, pp. 1133-1139.

Henley, N., Raffin, S. and Caemmerer, B. (2011), "The application of marketing principles to a social marketing campaign”, Marketing Intelligence \& Planning, Vol. 29 No. 7, pp. 697-706.

Hoffman, J.A., Morris, V. and Cook, J. (2009), “The Boston Middle School - Corner Store Initiative: Development, implementation, and initial evaluation of a program designed to improve adolescents' beverage - purchasing behaviours”, Psychology in the Schools, Vol. 46 No. 8, pp. 756-766.

Huhman, M., Bauman, A., and Bowles, H.R. (2008), "Initial outcomes of the VERB campaign: Tweens' awareness and understanding of campaign messages”, American Journal of Preventive Medicine, Vol. 34 No. 6, pp. 241-248.

Johnson, S.L., Bellows, L., Beckstrom, L. and Anderson, J. (2007), "Evaluation of a social marketing campaign targeting preschool children”, American Journal of Health Behaviour, Vol. 31 No. 1, pp. 44-55.

Johnston, Y., Denniston, R., Morgan, M., and Bordeau, M. (2009), "Steps to a healthier New York Rock On Café: Achieving sustainable systems changes in school lunch programs”, Health Promotion Practice, Vol. 10 No. 2, pp. 100-108.

Keihner, A.J., Meigs, R., Sugerman, S., Backman, D., Garbolino, T. and Mitchell, P. (2011), “The Power Play! Campaign’s school idea \& resource kits improve determinants of fruit and vegetable intake and physical activity among fourthand fifth-grade children”, Journal of Nutrition Education and Behavior, Vol. 43 
4S2, pp. 122-129.

Kremer, P., Waqa, G., Vanualailai, N., Schultz, J.T., Roberts, G., Moodie, M., ... and Swinburn, B.A. (2011), "Reducing unhealthy weight gain in Fijian adolescents: results of the Healthy Youth Healthy Communities study”, Obesity Reviews, Vol. 12 s2, pp. 29-40.

Levebvre, R.C. and Flora, J.A. (1988), "Social marketing and public health intervention”, Health Education Quarterly, Vol. 15, pp. 299.

Levine, E., Olander, C., Lefebvre, C., Cusick, P., Biesiadecki, L. and McGoldrick, D. (2002), "The team nutrition pilot study: Lessons learned from implementing a comprehensive school-based intervention”, Journal of Nutrition Education and Behaviour, Vol. 34 No. 2, pp. 109-116.

Lobstein, T., Baur, L. and Uauy, R. (2004), "Obesity in children and young people: A crisis in public health”, Obesity Reviews, Vol. 5 Suppl.:1, pp. 4-85.

Magarey, A.M., Daniels, L.A. and Boulton, T.J.C. (2001), "Prevalence of overweight and obesity in Australian children and adolescents: reassessment of 1985 and 1995 data against new standard international definitions”, Medical Journal of Australia, Vol. 174 No. 11, pp. 561-564

Ogden, C.L., Carroll, M.D., Kit, B.K. and Flegal, K.M. (2012), "Prevalence of obesity and trends in body mass index among US children and adolescents, 1999-2010", The Journal of the American Medical Association, Vol. 307, No. 5, pp. 483-90.

Pempek, T.A. and Calvert, S.L. (2009), "Tipping the balance: use of advergames to promote consumption of nutritious foods and beverages by low-income African American children”, Archives of Pediatrics \& Adolescent Medicine, Vol. 163 No. 7, pp. 633.

Raju, S., Rajagopal, P. and Gilbride, T. J. (2010), "Marketing healthful eating to children: the effectiveness of incentives, pledges, and competitions", Journal of Marketing, Vol. 74 No. 3, pp. 93-106.

Richards, J., Hackett, A., Duggan, B., Ellis, T., Forrest, D. and Grey, P. (2009), “An evaluation of an attempt to change the snacking habits of pre-school children using social marketing”, Public Health, Vol. 123, pp. 31-37.

Robinson-Maynard, A., Meaton, J. and Lowry, R. (2013), "Identifying key criteria as predictors of success in social marketing: Establishing an evaluation template and grid”, In: Kubacki, K. and Rundle-Thiele, S. (eds.) Contemporary Issues in Social Marketing, Cambridge Scholars Publishing.

Sallis, J.F., McKenzie, T.L., Conway, T.L., Elder, J.P., Prochaska, J.J., Brown, M., ... and Alcaraz, J.E. (2003), "Environmental interventions for eating and physical activity: a randomized controlled trial in middle schools", American Journal of Preventive Medicine, Vol. 24 No. 3, pp. 209-217.

Sanigorski, A.M., Bell, A.C., Kremer, P.J., Cuttler, R. and Swinburn, B.A. (2008), "Reducing unhealthy weight gain in children through community capacitybuilding: results of a quasi-experimental intervention program, Be Active Eat Well”, International Journal of Obesity, Vol. 32 No. 7, pp. 1060-1067.

Sayers, S.P., LeMaster, J.W., Thomas, I.M., Petroski, G.F. and Ge, B. (2012), "Bike, walk, and wheel: a way of life in Columbia, Missouri, revisited”, American Journal of Preventive Medicine, Vol. 43 No. 5, pp. 379-383.

Shonkoff, J.P., Boyce, W.T., and McEwen, B.S. (2009), “Neuroscience, molecular biology, and the childhood roots of health disparities: building a new framework for health promotion and disease prevention”, Jama, Vol. 301 No. 21, pp. 2252-2259.

Thackeray, R., Neiger, B.L., Leonard, H., Ware, J. and Stoddard, G.J. (2002), 
"Comparison of a 5-A-Day social marketing intervention and school based curriculum”, American Journal of Health Studies, Vol. 18 No. 1, pp. 46-54.

Wang, Y. and Lobstein, T. (2006), "Worldwide trends in childhood overweight and obesity”, International Journal of Pediatric Obesity, Vol. 1 No. 1, pp. 11-25.

World Health Organization (2000), Obesity: preventing and managing the global epidemic, WHO Technical Report Series 894. Geneva: World Health Organization, available: http://www.who.int/nutrition/publications/obesity/WHO_TRS_894/en/, accessed 14 August 2014.

World Health Organization (2003), Obesity and overweight, Factsheet, available at: http://www.who.int/dietphysicalactivity/media/en/gsfs_obesity.pdf, accessed 15 October 2014.

World Health Organization (2014), Childhood overweight and obesity, available: http://www.who.int/dietphysicalactivity/childhood/en/, accessed 15 October 2014. 


\section{Appendix 1}

81 articles included in the analysis of 23 social marketing interventions.

\begin{tabular}{|c|c|c|}
\hline No. & Intervention & Articles included \\
\hline 1 & $\begin{array}{l}\text { Atlantis et } \\
\text { al., } 2008\end{array}$ & $\begin{array}{l}\text { Atlantis, E., Salmon, J., \& Bauman, A. (2008). Acute effects of advertisements on children's choices, preferences, and ratings of liking for physical } \\
\text { activities and sedentary behaviours: A randomised controlled pilot study. Journal of Science and Medicine in Sport, 11(6), 553-557. } \\
\text { Elliott, D. \& Walker, D. (2007). Evaluation of the national 'Get Moving' campaign. Woolcott Research. Retrieved from: } \\
\text { http://www.healthyactive.gov.au/internet/healthyactive/publishing.nsf/Content/CD99B2A715DB9214CA2572DC001855A8/\$File/getmoving-eval- } \\
\text { jul07.pdf }\end{array}$ \\
\hline 2 & $\begin{array}{l}\text { Bachar et al., } \\
2006\end{array}$ & $\begin{array}{l}\text { Bachar, J.J., Lefler, L.J., Reed, L., McCoy, T., Bailey, R., \& Bell, R. (2006). Cherokee Choices: a diabetes prevention program for American Indians. } \\
\text { Preventing Chronic Disease, 3(3), 1-9. } \\
\text { Anon. (n.d.) Cherokee Choices Diabetes Prevention Program for Native American Cherokee Indians (USA-Government). Retrieved from: } \\
\text { http://www.gken.org/Synopses/CI_10006.pdf } \\
\text { Bachar, J. (2011a). Cherokee Choices: A Diabetes Prevention Program in Cherokee, North Carolina. North Caroline Medical Journal, 72(5), } 394-395 . \\
\begin{array}{l}\text { Bachar, J. (2011b). REACHing Eastern Band of Cherokee Indians in Cherokee, North Caroline. Retrieved from: } \\
\text { http://usphsicon.files.wordpress.com/2011/03/cherokee_choices.pdf }\end{array}\end{array}$ \\
\hline 3 & $\begin{array}{l}\text { Bellows et } \\
\text { al., } 2013\end{array}$ & $\begin{array}{l}\text { Bellows, L.L., Davies, P.L., Anderson, J., \& Kennedy, C. (2013). Effectiveness of a physical activity intervention for head start preschoolers: a } \\
\text { randomized intervention study. The American Journal of Occupational Therapy, 67(1), 28-36. } \\
\text { Bellows, L., Silvernail, S., Caldwell, L., Bryant, A., Kennedy, C., Davies, P., \& Anderson, J. (2011). Parental perception on the efficacy of a physical } \\
\text { activity program for preschoolers. Journal of Community Health, 36(2), 231-237. } \\
\text { Bellows, L., Anderson, J., Davies, P., \& Kennedy, C. (2009). Integration of social marketing elements in the design of a physical activity program for } \\
\text { preschoolers. Social Marketing Quarterly, 15(1), 2-21. }\end{array}$ \\
\hline 4 & Cork, 2008 & Cork, S. (2008). Beating the barriers to social marketing. Social Marketing Quarterly, 14(1), 37-49. \\
\hline 5 & $\begin{array}{l}\text { Croker et al., } \\
2012\end{array}$ & $\begin{array}{l}\text { Croker, H., Lucas, R., \& Wardle, J. (2012). Cluster-randomised trial to evaluate the 'Change for Life'mass media/social marketing campaign in the } \\
\text { UK. BMC Public Health, 12(1), } 404 . \\
\text { Department of Health. (2008). Healthy weight, healthy lives: Consumer insight summary. Retrieved from: http://www.nhs.uk/change4life/supporter- } \\
\text { resources/downloads/consumer_insight.pdf }\end{array}$ \\
\hline
\end{tabular}




\begin{tabular}{|c|c|c|}
\hline & & 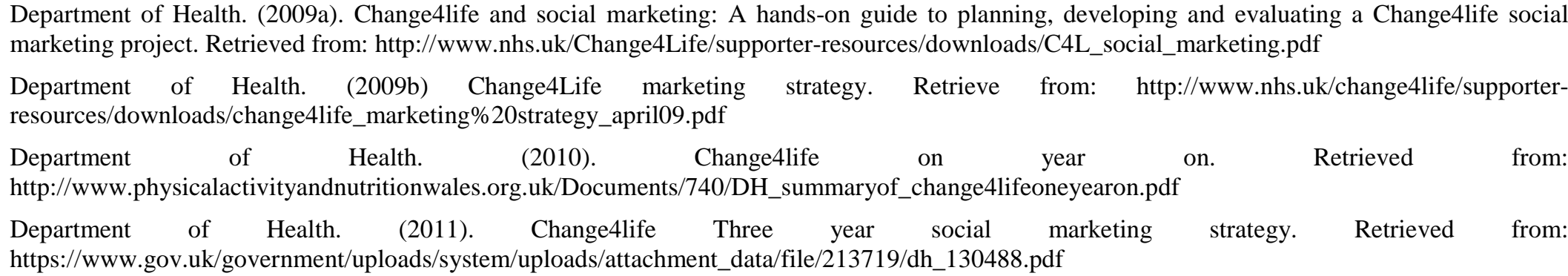 \\
\hline 6 & $\begin{array}{l}\text { DeBar et al., } \\
2009\end{array}$ & $\begin{array}{l}\text { DeBar, L.L., Schneider, M., Ford, E.G., Hernandez, A.E., Showell, B., Drews, K. L., ... \& White, M. (2009). Social marketing-based communications } \\
\text { to integrate and support the HEALTHY study intervention. International Journal of Obesity, 33, 52-59. } \\
\text { Gillis, B., Mobley, C., Stadler, D.D., Hartstein, J., Virus, A., \& Volpe, S. L. (2009). Rationale, design and methods of the HEALTHY study nutrition } \\
\text { intervention component. International Journal of Obesity, 33, 29-36. } \\
\text { Hirst, K., Baranowski, T., DeBar, L., Foster, G.D., Kaufman, F., Kennel, P., ... \& Ford, D. (2009). HEALTHY study rationale, design and methods: } \\
\text { moderating risk of type } 2 \text { diabetes in multi-ethnic middle school students. International Journal of Obesity (2005), 33, 4-20. } \\
\text { Jago, R., McMurray, R.G., Drews, K.L., Moe, E.L., Murray, T., Pham, T.H., ... \& Volpe, S. L. (2011). HEALTHY intervention: fitness, physical } \\
\text { activity, and metabolic syndrome results. Medicine and Science in Sports and Exercise, 43(8), 1513. } \\
\text { Kaufman, F., Hirst, K., Buse, J., Foster, G.D., Goldberg, L., Schneider, M., .. \& Yin, Z. (2011). Effect of Secular Trends on a Primary Prevention } \\
\text { Trial: The HEALTHY Study Experience. Childhood Obesity (Formerly Obesity and Weight Management), 7(4), 291-297. } \\
\text { Siega-Riz, A.M., El Ghormli, L., Mobley, C., Gillis, B., Stadler, D., Hartstein, J., ... \& Bridgman, J. (2011). The effects of the HEALTHY study } \\
\text { intervention on middle school student dietary intakes. International Journal of Behavioral Nutrition and Physical Activity, 8(7). } \\
\text { Willi, S.M., Hirst, K., Jago, R., Buse, J., Kaufman, F., Bassin, S., ... \& Hale, D. E. (2012). Cardiovascular risk factors in multi-ethnic middle school } \\
\text { students: the HEALTHY primary prevention trial. Pediatric Obesity, 7(3), 230-239. }\end{array}$ \\
\hline 7 & $\begin{array}{l}\text { Evans et al., } \\
2006\end{array}$ & $\begin{array}{l}\text { Evans, A.E., Dave, J., Tanner, A., Duhe, S., Condrasky, M., Wilson, D., ... \& Evans, M. (2006). Changing the home nutrition environment: effects of } \\
\text { a nutrition and media literacy pilot intervention. Family \& Community Health, 29(1), 43-54. } \\
\text { Tanner, A., Duhe, S., Evans, A., \& Condrasky, M. (2008). Using Student-Produced Media to Promote Healthy Eating A Pilot Study on the Effects of a } \\
\text { Media and Nutrition Intervention. Science Communication, 30(1), 108-125. }\end{array}$ \\
\hline 8 & $\begin{array}{l}\text { Foster et al., } \\
2008\end{array}$ & $\begin{array}{l}\text { Foster, G.D., Sherman, S., Borradaile, K.E., Grundy, K.M., Vander Veur, S.S., Nachmani, J., ... \& Shults, J. (2008). A policy-based school } \\
\text { intervention to prevent overweight and obesity. Pediatrics, 121(4), 794-802. }\end{array}$ \\
\hline
\end{tabular}




\begin{tabular}{|c|c|c|}
\hline 9 & $\begin{array}{l}\text { Henley et } \\
\text { al., } 2011\end{array}$ & $\begin{array}{l}\text { Henley, N., Raffin, S., \& Caemmerer, B. (2011). The application of marketing principles to a social marketing campaign. Marketing Intelligence \& } \\
\text { Planning, 29(7), 697-706. } \\
\text { Ayadi, K., \& Young, B. (2006). Community partnerships: preventing childhood obesity. Young Consumers: Insight and Ideas for Responsible } \\
\text { Marketers, 7(4), 35-40. } \\
\text { Borys, J.M., Le Bodo, Y., Jebb, S.A., Seidell, J.C., Summerbell, C., Richard, D., .. \& S Swinburn, B. (2012). EPODE approach for childhood obesity } \\
\text { prevention: methods, progress and international development. Obesity Reviews, 13(4), 299-315. } \\
\text { Borys, J.M., Le Bodo, Y., De Henauw, S., Moreno, L.A., Romon, M., Seidell, J C., \& Visscher, T. (2011). Preventing Childhood Obesity: Epode } \\
\text { European Network Recommendations. Lavoisier. } \\
\text { Van Koperen, T.M., Jebb, S.A., Summerbell, C.D., Visscher, T.L.S., Romon, M., Borys, J.M., \& Seidell, J.C. (2013). Characterizing the EPODE logic } \\
\text { model: unravelling the past and informing the future. Obesity Reviews, 14(2), 162-170. }\end{array}$ \\
\hline 10 & $\begin{array}{l}\text { Hoffman et } \\
\text { al., } 2009\end{array}$ & $\begin{array}{l}\text { Hoffman, J.A., Morris, V., \& Cook, J. (2009). The Boston Middle School-Corner Store Initiative: Development, implementation, and initial } \\
\text { evaluation of a program designed to improve adolescents' beverage-purchasing behaviours. Psychology in the Schools, 46(8), 756-766. }\end{array}$ \\
\hline 11 & $\begin{array}{l}\text { Huhman } \\
\text { al., } 2008\end{array}$ & $\begin{array}{l}\text { Huhman, M., Bauman, A., \& Bowles, H.R. (2008). Initial Outcomes of the VERB Campaign: Tweens' Awareness and Understanding of Campaign } \\
\text { Messages. American Journal of Preventive Medicine, 34(6), 241-248. } \\
\text { Asbury, L.D., Wong, F.L., Price, S.M., \& Nolin, M.J. (2008). The VERB Campaign: Applying a Branding Strategy in Public Health. American } \\
\text { Journal of Preventive Medicine, 34(6), 183-187. } \\
\text { Bauman, A. (2004). Commentary on the VERB }{ }^{\mathrm{TM}} \text { campaign-perspectives on social marketing to encourage physical activity among youth. } \\
\text { Preventing Chronic Disease, 1(3), 1-3. } \\
\text { Bauman, A., Bowles, H.R., Huhman, M., Heitzler, C.D., Owen, N., Smith, B.J., \& Reger-Nash, B. (2008). Testing a hierarchy-of-effects model: } \\
\text { pathways from awareness to outcomes in the VERB }{ }^{\mathrm{TM}} \text { campaign 2002-2003. American Journal of Preventive Medicine, 34(6), 249-256. } \\
\text { Berkowitz, J.M., Huhman, M., Heitzler, C.D., Potter, L.D., Nolin, M.J., \& Banspach, S.W. (2008). Overview of Formative, Process, and Outcome } \\
\text { Evaluation Methods Used in the VERB Campaign. American Journal of Preventive Medicine, 34(6), 222-229. } \\
\text { Berkowitz, J.M., Huhman, M., \& Nolin, M.J. (2008). Did Augmenting the VERB Campaign Advertising in Select Communities Have an Effect on } \\
\text { Awareness, Attitudes, and Physical Activity?. American Journal of Preventive Medicine, 34(6), 257-266. } \\
\text { Bretthauer-Mueller, R., Berkowitz, J.M., Thomas, M., McCarthy, S., Green, L. A., Melancon, H., .. \& Dodge, K. (2008). Catalysing community } \\
\text { action within a national campaign: VERB }{ }^{\mathrm{TM}} \text { community and national partnerships. American Journal of Preventive Medicine, 34(6), 210-221. } \\
\text { Bretthauer-Mueller, R., \& Melancon, H. (2005). VERB }{ }^{\mathrm{TM}} \text { Campaign: Extending the Reach of a National Campaign to Ethnically Diverse Audiences. } \\
\text { Preventing Chronic Disease, 2(2), 1. }\end{array}$ \\
\hline
\end{tabular}




\begin{tabular}{|c|c|c|}
\hline & & 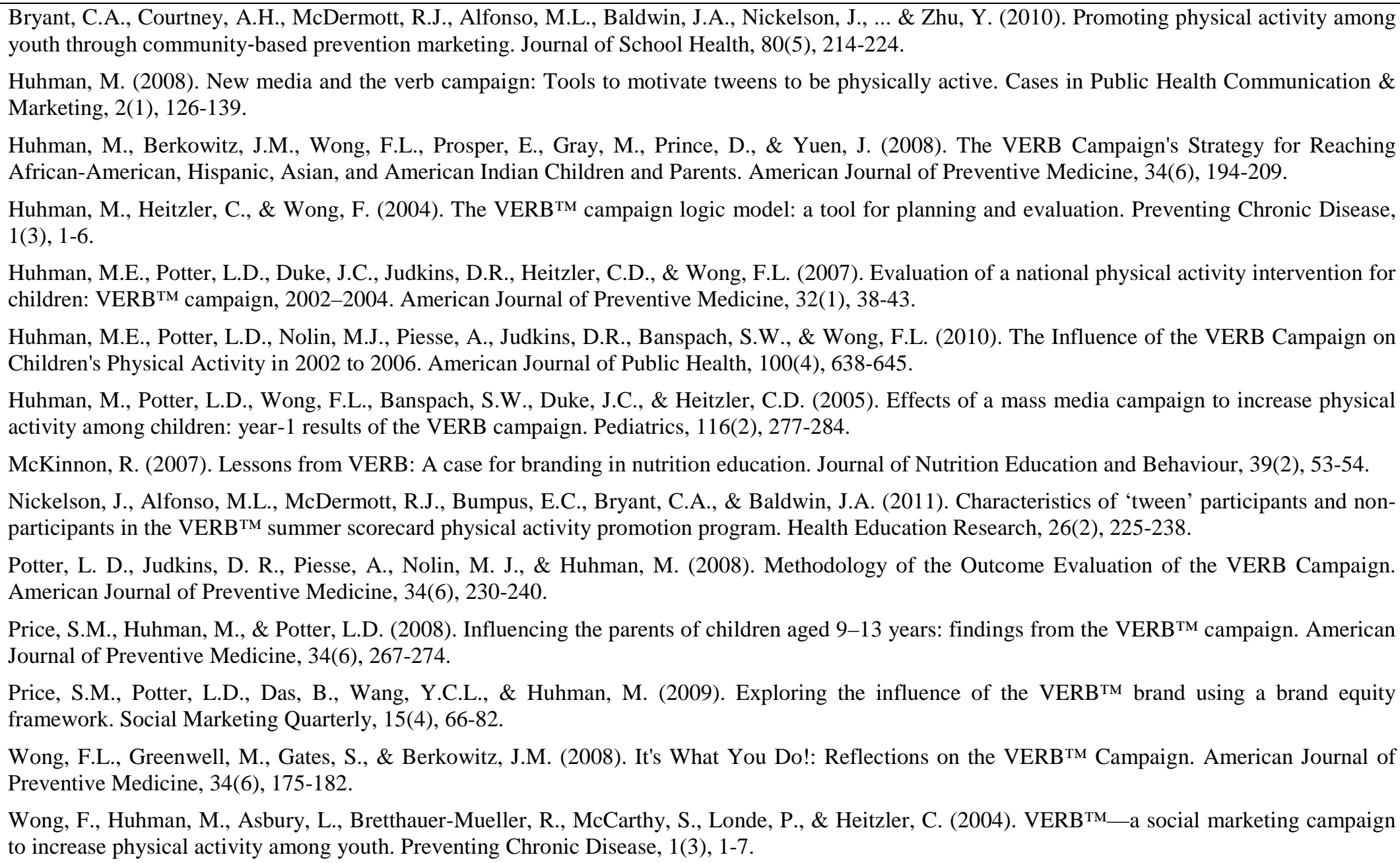 \\
\hline 12 & $\begin{array}{l}\text { Johnson et } \\
\text { al., } 2007\end{array}$ & $\begin{array}{l}\text { Johnson, S.L., Bellows, L., Beckstrom, L., \& Anderson, J. (2007). Evaluation of a social marketing campaign targeting preschool children. American } \\
\text { Journal of Health Behaviour, 31(1), 44-55. }\end{array}$ \\
\hline
\end{tabular}




\begin{tabular}{|c|c|c|}
\hline & & $\begin{array}{l}\text { Bellows, L., \& Anderson, J. (2006). The Food Friends: Encouraging Preschoolers to Try New Foods. Young Children, 61(3), 37-39. } \\
\text { Bellows, L., Anderson, J., Gould, S.M., \& Auld, G. (2008). Formative research and strategic development of a physical activity component to a social } \\
\text { marketing campaign for obesity prevention in preschoolers. Journal of Community Health, 33(3), 169-178. } \\
\text { Bellows, L., Cole, K., \& Anderson, J. (2006). Assessing characteristics, needs, and preferences of a secondary audience for the development of a } \\
\text { bilingual parent component to the food friends social marketing campaign. Social Marketing Quarterly, 12(2), 43-57. } \\
\text { Bellows, L., Silvernail, S., Caldwell, L., Bryant, A., Kennedy, C., Davies, P., \& Anderson, J. (2011). Parental perception on the efficacy of a physical } \\
\text { activity program for preschoolers. Journal of Community Health, 36(2), 231-237. } \\
\text { Young, L., Anderson, J., Beckstrom, L., Bellows, L., \& Johnson, S.L. (2004). Using social marketing principles to guide the development of a } \\
\text { nutrition education initiative for preschool-aged children. Journal of Nutrition Education and Behaviour, 36(5), 250-257. }\end{array}$ \\
\hline 13 & $\begin{array}{l}\text { Johnston et } \\
\text { al., } 2009\end{array}$ & $\begin{array}{l}\text { Johnston, Y., Denniston, R., Morgan, M., \& Bordeau, M. (2009). Steps to a healthier New York Rock On Café: Achieving sustainable systems } \\
\text { changes in school lunch programs. Health Promotion Practice, 10(2), 100-108. }\end{array}$ \\
\hline 14 & $\begin{array}{l}\text { Keihner et } \\
\text { al., } 2011\end{array}$ & $\begin{array}{l}\text { Keihner, A.J., Meigs, R., Sugerman, S., Backman, D., Garbolino, T., \& Mitchell, P. (2011). The Power Play! Campaign’s school Idea \& Resource } \\
\text { Kits improve determinants of fruit and vegetable intake and physical activity among fourth- and fifth-grade children. Journal of Nutrition Education } \\
\text { and Behavior, 43(4S2), 122-129. } \\
\text { Foerster, S.B., Gregson, J., Geall, D.L., Hudes, M., Magnuson, H., Livingston, S., Davis, M.A., Joy, A.B., \& Garbolino, T. (1998). The California } \\
\text { children’s } 5 \text { a day - Power Play! Campaign: evaluation of a large-scale social marketing initiative. Family \& Community Health, 21(1), 46-64. } \\
\text { Garmezy, N. (1996). Reflections and commentary on risk, resilience, and development. Stress, risk, and resilience in children and adolescents, 1-15. } \\
\text { Keihner, A.J., Garbolino, T., \& Hudes, M. (2004). Findings from the } 1999 \text { California Children's Healthy Eating and Exercise Practices Survey: } \\
\text { Intervention Implications and Campaign Evaluation. California Department of Health Services, Public Health Institute, September } 2004 . \\
\text { Public Health Institute (2002). A Special Report on Policy Implications from the } 1999 \text { California Children's Healthy Eating and Exercise Practices } \\
\text { Survey. Public Health Institute, Revised August 2002. } \\
\text { Sugerman, S. (2008). Successful Evaluation Strategies: California. Cancer Prevention and Nutrition Section; California Department of Public Health, } \\
\text { February 21, 2008. Retrieved from: http://www.nifa.usda.gov/nea/food/fsne/pdfs/asnna_evaluation.pdf }\end{array}$ \\
\hline 15 & $\begin{array}{l}\text { Kremer et } \\
\text { al., } 2011\end{array}$ & $\begin{array}{l}\text { Kremer, P., Waqa, G., Vanualailai, N., Schultz, J.T., Roberts, G., Moodie, M., .. \& Swinburn, B.A. (2011). Reducing unhealthy weight gain in Fijian } \\
\text { adolescents: results of the Healthy Youth Healthy Communities study. Obesity Reviews, 12(s2), 29-40. } \\
\text { Schultz, J., Utter, J., Mathews, L., Cama, T., Mavoa, H., \& Swinburn, B. (2007). The Pacific OPIC project (Obesity Prevention in Communities): } \\
\text { action plans and interventions. Pacific Health Dialog, 14(2), 147-53. } \\
\text { Swinburn, B.A., Millar, L., Utter, J., Kremer, P., Moodie, M., Mavoa, H., ... \& Scragg, R. (2011). The Pacific Obesity Prevention in Communities }\end{array}$ \\
\hline
\end{tabular}




\begin{tabular}{|c|c|c|}
\hline & & $\begin{array}{l}\text { project: project overview and methods. Obesity Reviews, 12(2), 3-11. } \\
\text { Swinburn, B., Pryor, J., McCabe, M., Carter, R., de Courten, M., Schaaf, D., \& Scragg, R. (2007). The Pacific OPIC project (Obesity Prevention in } \\
\text { Communities)-objectives and designs. Pacific Health Dialog, 14(2), 139-46. }\end{array}$ \\
\hline \multirow{2}{*}{16} & \multirow{2}{*}{$\begin{array}{l}\text { Levine et al., } \\
2002\end{array}$} & $\begin{array}{l}\text { Levine, E., Olander, C., Lefebvre, C., Cusick, P., Biesiadecki, L., \& McGoldrick, D. (2002). The team nutrition pilot study: Lessons learned from } \\
\text { implementing a comprehensive school-based intervention. Journal of Nutrition Education and Behaviour, 34(2), 109-116. }\end{array}$ \\
\hline & & $\begin{array}{l}\text { The Story of Team Nutrition: Final Report. Executive summary of the pilot study. (1998). U.S. Department of Agriculture, Food and Nutrition } \\
\text { Service, Office of Analysis, Nutrition, and Evaluation. Retrieved from: http://www.fns.usda.gov/ora/menu/published/cnp/FILES/tn2execsum.pdf }\end{array}$ \\
\hline 17 & $\begin{array}{l}\text { Pempek and } \\
\text { Calvert, } \\
2009\end{array}$ & $\begin{array}{l}\text { Pempek, T.A., \& Calvert, S.L. (2009). Tipping the balance: use of advergames to promote consumption of nutritious foods and beverages by low- } \\
\text { income African American children. Archives of Pediatrics \& Adolescent Medicine, 163(7), } 633 \text {. }\end{array}$ \\
\hline 18 & $\begin{array}{l}\text { Raju et al., } \\
2010\end{array}$ & $\begin{array}{l}\text { Raju, S., Rajagopal, P., \& Gilbride, T. J. (2010). Marketing healthful eating to children: the effectiveness of incentives, pledges, and competitions. } \\
\text { Journal of Marketing, 74(3), 93-106. }\end{array}$ \\
\hline 19 & $\begin{array}{l}\text { Richards et } \\
\text { al., } 2009\end{array}$ & $\begin{array}{l}\text { Richards, J., Hackett, A., Duggan, B., Ellis, T., Forrest, D., \& Grey, P. (2009). An evaluation of an attempt to change the snacking habits of pre- } \\
\text { school children using social marketing. Public Health, 123, 31-37. }\end{array}$ \\
\hline 20 & $\begin{array}{l}\text { Sallis et al., } \\
2003\end{array}$ & $\begin{array}{l}\text { Sallis, J.F., McKenzie, T.L., Conway, T.L., Elder, J.P., Prochaska, J.J., Brown, M., .. \& Alcaraz, J.E. (2003). Environmental interventions for eating } \\
\text { and physical activity: a randomized controlled trial in middle schools. American Journal of Preventive Medicine, 24(3), } 209-217 .\end{array}$ \\
\hline 21 & $\begin{array}{l}\text { Sanigorski et } \\
\text { al., } 2008\end{array}$ & $\begin{array}{l}\text { Sanigorski, A.M., Bell, A.C., Kremer, P.J., Cuttler, R., \& Swinburn, B.A. (2008). Reducing unhealthy weight gain in children through community } \\
\text { capacity-building: results of a quasi-experimental intervention program, Be Active Eat Well. International Journal of Obesity, 32(7), 1060-1067. } \\
\text { Bell, A.C., Simmons, A., Sanigorski, A.M., Kremer, P.J., \& Swinburn, B.A. (2008). Preventing childhood obesity: the sentinel site for obesity } \\
\text { prevention in Victoria, Australia. Health Promotion International, 23(4), 328-336. }\end{array}$ \\
\hline & & $\begin{array}{l}\text { Nichols, M.S., de Silva-Sanigorski, A.M., Cleary, J.E., Goldfeld, S.R., Colahan, A., \& Swinburn, B.A. (2011). Decreasing trends in overweight and } \\
\text { obesity among an Australian population of preschool children. International Journal of Obesity, 35(7), 916-924. }\end{array}$ \\
\hline 22 & Sayers et al., & $\begin{array}{l}\text { Sayers, S.P., LeMaster, J.W., Thomas, I.M., Petroski, G.F., \& Ge, B. (2012). Bike, walk, and wheel: a way of life in Columbia, Missouri, revisited. } \\
\text { American Journal of Preventive Medicine, 43(5), 379-383. }\end{array}$ \\
\hline & & Thomas, I.M., Sayers, S.P., Godon, J.L., \& Reilly, S.R. (2009). Bike, walk, and wheel: a way of life in Columbia, Missouri. American Journal of \\
\hline 23 & Thackeray et & Thackeray, R., Neiger, B.L., Leonard, H., Ware, J., \& Stoddard, G.J. (2002). Comparison of a 5-A-Day Social Marketing Intervention and School \\
\hline
\end{tabular}


